\title{
The impact of risk management on internal and sustainable growth rate: Evidence from Tehran Stock Exchange
}

\author{
Hamid Reza Vakili Fard, Ali Alizadeh* and Karim Ghalmagh
}

Department of Financial Management, Science and Research Branch, Islamic Azad University, Tehran, Iran

\begin{tabular}{l}
\hline C H R O N I C L E \\
\hline Article history: \\
Received January 20, 2014 \\
Accepted 30 August 2014 \\
Available online \\
August 302014 \\
\hline Operating leverage \\
Financial leverage \\
Combined leverage \\
Internal growth rate \\
Sustainable growth rate \\
Tehran Stock Exchange \\
\end{tabular}
A B S T R A C T

\begin{abstract}
Measuring the relative risk of firms has been an open discussion among researchers. There are many studies on learning how leverage may influence on growth of the firms. This article reviews the relationship between risk management, internal and sustainable growth of accepted companies in Tehran stock exchange. The survey considers three types of risks including operating, financial and compound and investigates their relationships with internal growth rate as well as sustainable growth rate. Using some regression techniques, the study has determined negative and meaningful relationships between different types of leverage on side and internal as well as sustainable growth on the other side.
\end{abstract}

\section{Introduction}

One of the most important issues in developing countries after second world war is associated with economic growth. The main theories related to economic growth is to verify growth factors in different countries. Economic growth in each country is subject to the growth of companies (Aivazian \& Callen, 1980). Lang et al. (1996) demonstrated that there was a negative relationship between leverage and future growth at the firm level and, for diversified firms, at the business segment level. This negative relationship between leverage and growth holds for companies with low Tobin's q ratio, but not for high-q firms or firms in high-q industries. They reported that, leverage could not reduce growth for companies known to have good investment opportunities, but was negatively associated with growth for firms whose growth opportunities were either not recognized by the capital markets or were not sufficiently valuable to overcome the effects of their debt overhang. Johnson (2003) investigated debt maturity and the impacts of growth opportunities and liquidity risk on leverage. They examined the hypothesis that short debt maturity attenuates the negative impact of growth opportunities on leverage. The study reported strong support for an economically significant attenuation effect. The negative effect of growth opportunities on leverage *Corresponding author.

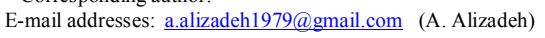


for firms with all shorter-term debt was less than one-sixth as large as the impact for companies with all longer-term debt. Short maturity also could increase liquidity risk, however, which negatively influenced on leverage. The results implied that firms' trade off the cost of underinvestment problems against the cost of liquidity risk when choosing short maturity.

In this research it is tried to review one of the most important factors in growth of companies include companies risk measured by operating, financial and combined leverage formula.

\section{Material and methods}

Dependent variables of this research is internal and sustainable growth rate and operating leverage independent variables, financial leverage and combined leverage is defined as following . risk management is one of the most important subject in companies that has a significant impact on growth of company according to investment and financial management theories. The above risk is divided into two main parts:

\subsection{Commercial risk (operating leverage)}

In this survey, risk associated with main operations of company is measured by operating leverage (OL) as follows,

$$
O L=\frac{Q(P-V)}{Q(P-V)-F},
$$

where $Q$ represents the number of production, $p$ states the price, $V$ indicates the variable cost and $F$ represents fixed cost of firm.

\subsection{Financial risk}

Risk associated with investment structure and financing methods of company, liability and investment, is measured by financing leverage (FL) as follows,

$$
F L=\frac{Y}{Y-I-\frac{E}{1-t}},
$$

where $Y$ represents operating profit of company, $I$ states total profit rate of company such as loan and income bonds, $E$ is associated with preferred equity profit and finally $t$ shows the rate of income tax of company. In addition, two internal growth rates are calculated for measuring the success of a firm.

\subsection{Internal growth rate}

Internal growth rate is associated with the rate of sales growth of firms. This ratio is achieved by applying internal sources of company including accumulative earning without any foreign financing, without borrowing from banks and other financial and credit institutes and issued bonds. This certainly is not the primary purpose of firms, because external sources of financing is a financial leverage, which helps us reach profitability. If company does not apply external sources of financing as loan in sales development of company, it may not reach its objectives. However, internal growth rate of company plays essential role in sustainable growth rate and reviewing growth rate is very important. Internal growth rate is calculated as follows,

$$
\begin{aligned}
& g=\frac{P . S . R}{A-P . S . R}, \\
& G=\frac{R O A}{1-R O A \times R},
\end{aligned}
$$

where, $P$ represents company profit margin, achieved by dividing the net profit on sales, $S$ states sales of the last year, $R$ is associated with percentage of income maintenance, $A$ stands for total 
assets and finally, $R O A$ represents rate of return on assets achieved by dividing net profit on total assets.

\subsection{Sustainable growth rate}

Sustainable growth rate is part of growth rate that company achieve without publication and sales of new share by using internal sources like accumulative profit and loan without any change in financial risk. Sustainable growth rate of company is calculated as follows,

$$
\begin{aligned}
& g^{*}=\frac{P\left(\frac{S}{A}\right)\left(1+\frac{D}{E}\right) R}{A-P\left(\frac{S}{A}\right)\left(1+\frac{D}{E}\right) R}, \\
& G=\frac{R O E \times R}{1-R O E \times R},
\end{aligned}
$$

where $P$ represents company profit margin (achieved by dividing net profit on sales of company), $S$ states sales of the last years, $R$ represents the percentage of income maintenance achieved by dividing increased rate in accumulative profit on net profit. In addition, $A$ states the total assets, $R O E$ states the rate of return of shareholders, which is calculated by dividing net profit on total equity of shareholders, $D$ states the total debts of company and finally, $E$ states the total shareholders' equities.

\section{Methodology}

This study is applicable based on its purpose because intends to review their efficiency on internal and sustainable growth rate of companies accepted in Tehran Stock Exchange (TSE) in risk management framework. The proposed study of this paper considers the following six hypotheses,

1. Operating leverage has a significant impact on internal growth rate of TSE listed firms.

2. Financial leverage has a significant impact on internal growth rate of TSE listed firms.

3. Compound leverage has a significant impact on internal growth rate of TSE listed firms.

4. Operating leverage has a significant impact on sustainable growth rate of TSE listed firms.

5. Financial leverage has a significant impact on sustainable growth rate of TSE listed firms.

6. Compound leverage has a significant impact on sustainable growth rate of TSE listed firms.

To test the above hypotheses, we look for a linear relationship between dependent variable and independent variables. In our survey, Operating leverage, financial leverage and compound leverage are independent variables and internal and sustainable growth rates are dependent variable.

Statistical population of this study includes all companies accepted on TSE exchange selected by classified random sampling. We have tried to include all small and big companies with high, averaged and low efficiency in samples. After gathering the required data, operating, financial and compound leverages, internal and sustainable growth rate are calculated. In order to review sustainability of time series, we have used unit root test by EVIEWS software. Then, hypotheses tests related to six sub-hypotheses have been performed by EVIEWS software. In our survey, we have achieved a high F-statistics for all models and there is a significant relationship between dependent and independent variables. All models were reviewed in terms of autocorrelation and there was no sign of correlation in all models. 
The first hypothesis of the survey investigates the effect of operating leverage on internal growth. In our regression implementation, Durbin-Watson ratio is equal to 1.97 , which means there was no autocorrelation. In addition, the t-student value associated with operating leverage is equal to 2.54, which is statistically significant $(\alpha=5 \%)$ and the coefficient is negative is negative, which confirms a reverse relationship between operating leverage and internal growth. Therefore, the first hypothesis of the survey is confirmed. The second hypothesis of this survey has investigated the relationship between internal growth and financial leverage. Similarly, we have found a negative and meaningful relationship between these two variables, which confirms the second hypothesis of the survey $(\alpha=$ $5 \%$ ). The third hypothesis of the survey studies the relationship between compound leverage and internal growth. In our survey, we have added AR(1) to adjust the correlation between residuals. One more time, we have found a negative and meaningful relationship between compound leverage and internal growth after adding AR(1) to the original model and we could confirm the third hypothesis of the survey. The fourth, fifth and sixth hypotheses of the survey were associated with the relationship between operating, financial and compound leverage and sustainable growth, respectively. In our survey, we have determined negative and meaningful relationship between independent variables and dependent variable when the level of significance was five percent. Therefore, we can confirm the next three hypotheses of the survey.

\section{Conclusions}

This paper has presented an empirical investigation to study the relationship between different types of leverages and internal as well as sustainable growth for some listed firm on Tehran stock exchange. The study has gathered the necessary data from available sources and using some linear regression models, the study has determined that there were negative and meaningful relationships between operating, financial as well as couponed leverages on one side and internal growth on the other side. In addition, the study has determined negative and meaningful relationships between operating, financial as well as couponed leverages on one side and sustainable growth on the other side. In previous researches, the major impact of variables related to risk management on the growth rate of companies has been specified and the type of relationship was reviewed (Adrian \& Shin, 2010; Dunne et al. 1989; Dehdar, 2001; Bakhterari, 2003).

\section{References}

Adrian, T., \& Shin, H. S. (2010). Liquidity and leverage. Journal of financial intermediation, 19(3), 418-437.

Aivazian, V. A., \& Callen, J. L. (1980). Corporate leverage and growth the game-theoretic issues. Journal of Financial Economics, 8(4), 379-399.

Bakhterari, M. (2003). Reviewed the impact of earning growth rate of company on prices in stock exchange. MA thesis, Emam sadegh university, Tehran, Iran.

Dehdar, F. (2001). A review the impact of earning growth rate of company on prices in stock exchange. MA thesis, Tehran university, Tehran, Iran.

Dunne, T., Roberts, M. J., \& Samuelson, L. (1989). The growth and failure of US manufacturing plants. The Quarterly Journal of Economics, 104(4), 671-698.

Johnson, S. A. (2003). Debt maturity and the effects of growth opportunities and liquidity risk on leverage. Review of Financial Studies, 16(1), 209-236.

Lang, L., Ofek, E., \& Stulz, R. (1996). Leverage, investment, and firm growth. Journal of financial Economics, 40(1), 3-29. 